are several fundamental systems, and it is customary to reduce any series of observations to one or other of these fundamental systems. If further series of observations are reduced to the Potsdam system, any future revision of this system can easily be extended to all the observa- tions based upon it. At present no series has been generally accepted as a standard, and if two determinations of magnitude of a star agree within one-tenth of a magnitude, astronomers now feel very satisfied.

(T'o be continued.)

\title{
The Development and Spread of Civilisation.
}

\author{
By W. J. Perry, The University, Manchester.
}

$\mathrm{R}^{\mathrm{E}}$ ECENT research suggests that the various forms of human culture are the result of a process of organic growth. Continuity is apparently the key-note of the study of the history of civilisation. But, because it is not possible in each case to supply the missing links, it is incumbent on those who believe in continuity to construct a mechanism of the development and spread of civilisation in all ages and places. The following generalisations suggest how this process has been effected.

It would seem that civilisation-that is to say, the possession of the fundamental arts and crafts necessary for settled corporate life-first appeared in the Near East. There, at some time before 3700 B.C., had apparently been discovered the crafts of agriculture, irrigation, stock-breeding, carpentry, metal-working, stone-working, potterymaking, weaving, and so on. All the rest of the world, so far as can be seen, was at that time peopled only by hunting tribes very low in the scale of culture. These were not long left in possession of their hunting-grounds, for civilisations began to appear in outlying parts of the earth, such as Turkestan, Siberia, China, India, the valley of the Wei in China, the valleys of the Usumacinta and Motagua in Guatemala, Lake Titicaca in Peru, etc. The cultural level of these early centres never exceeded, and rarely approached, that of the Near East. Around these centres appeared later other civilisations, usually progressively lower in cultural level as they became more remote from the centre in space and time. For example, the earliest known civilised settlement of North America was that of the first Maya cities of Guatemala. All the later Maya cities, and the tribes that afterwards occupied the same region, display a definite inferiority of technique in the arts and crafts as compared with these earliest settlements. Northward from Mexico there is a steady drop in the level of culture. Similarly with South America. It is claimed that negro Africa derived practically all its culture, directly or indirectly, from Egypt. As one goes south from Egypt there is, speaking venerally, a steady decline in cultural level, the most southerly people of all, the Hottentots and Bushmen, being the lowest. The study of the beginnings of European civilisation reveals a similar condition of affairs. The earliest centre was in the eastern Mediterranean. In no other
Iregion of the continent did ancient civilisation attain to so high a level, and the various stages of development of culture appeared later in time in the outlying parts than in those nearer to this region.

It is natural to seek to interpret these and similar facts. In only one region in the worldthe Near East--can progressive development of culture be established in ancient times. In that region civilisation probably first appeared, and there it reached the highest level of antiquity. Everywhere in the world outside the area directly and continuously influenced by this region, the story from the beginning is one of uninterrupted degeneration in arts and crafts. In many instances it is possible in these outlying regions to establish direct filiation of culture, and it is invariably found that the process is accompanied by degeneration in the arts and crafts. Since in any one region, such as America, it is found that, wherever direct cultural sequence can be established, the earlier is the more advanced, and that the earliest known culture is the most advanced of all in the technique of the arts and crafts, it is difficult to account for the facts otherwise than by postulating that the earliest civilisation in such a region was derived from one that preceded it in some other part of the world. Carried to its conclusion, this amounts to claiming that every. where outside the Near East, even in cases where it cannot be established by direct proof, culture exists by reason of direct filiation-in short, it amounts to postulating continuity in culture. In that way it would be claimed that the civilisations surrounding the original culture centres were derived from them, and that the culture centres themselves were derived from those that preceded them on the earth. The chronological argument would thus lead us to derive all the outlying culture centres from the Near East, and the whole process of cultural development would be one of growth outward from the Near East. This solution would satisfy both the spatial and chronological conditions of the problem.

The indication of a motive will tend to facilitate belief in such a world-wide movement of culture in antiquity. The ancient civilisations in different parts of the earth are fundamentally similar-they are all founded on irrigation-and in their economic. social, political, and religious organisa-

No. 2683 , vOL. IO7] 
tion they resemble the civilisations of the Near East. Further, in those early days there was a widespread belief in the efficacy of gold and other substances as "givers of life," and there are historical instances of expeditions setting out to seek for the earthly paradise, where such substances could be found-in America there are traditions of the arrival of highly civilised strangers on such an errand. The early sites of civilisation in the outlying parts of the world are near sources of gold, pearls, and other substances formerly credited with life-giving powers. So there is reason for concluding that there was a great movement of culture, the chief motive for which was the search for the elixir of life.

The ancients have left their traces on most of the goldfields and other similar sources of wealth of the earth, and they were apparently searching for others; but this search was abruptly abandoned. Regions that must have hummed with activity in days long past have, during many centuries, been peopled by tribes indifferent to the wealth at their disposal, so that goldfields worked thousands of years ago have only recently been reopened.

It is necessary to account for the fact that the early civilisation of the world carried within itself the germs of its decay and even destruction.

In the Near East appeared the first ruling class known to us. The kings there were from the first intimately associated with the maintenance of the irrigation systems on which such early communities chiefly depended for their food supply. In the earliest civilisations in the outlying parts of the earth there were ruling families so closely allied in their peculiar culture to those of the Near East that there is reason to believe that they were derived thence, directly or indirectly.

The process is known by which the new communities were formed around the old centres of civilisation. Members of the ruling class went out from their homes and imposed themselves elsewhere as a new ruling class, and this process has gone on until the earth has become covered with a network of States formed of a ruling class dominating people differing from them in culture and often in race. From the beginning, ruling classes have possessed beliefs and practices peculiar to themselves; they universally use heraldic emblems, the lion and the eagle playing a prominent part in connection with the kingship; a claim is often made to descent from an ancestor borne to a god by an earthly mother; in the early States we find the belief in a land of the dead in the sky invariably associated with the ruling class; the kings of the earlier States were supposed to be responsible for the welfare of the community; and there is a widespread association between royalty, the building of pyramids, and the preservation of the dead-all of which goes to support the theory that the ruling class of any country is derived from that of some other country, so that all the ruling classes of the world have NO. 2683 , VOL. IO7] originated ultimately by a continuous developing process from one group in the Near East, the place where they can first be detected.

The earliest peoples on the earth used no weapons that we have traces of, and the study of the remains of the Upper Palæolithic and Neolithic ages shows that these peoples were mainly, if not entirely, peaceful. The hunting tribes that live on the earth are all peaceful, and their standard of behaviour and morality is higher than that of civilised communities. War is the accompaniment of ruling classes. In their beginnings in all parts of the earth they did not indulge much in war, except to obtain slaves and victims for sacrifice, but the ruling classes of the daughter States struggled with each other for the possession of power and wealth; and often a military genius arose among them who welded many communities by conquest into an empire that usually fell to pieces on his death or defeat at the hands of some rival. In this way much of the old civilisation of the earth was destroyed, and the arrival of barbarians with ruling classes derived from more advanced peoples can, in a large number of cases, be shown to account for the sudden cessation of the onward march of civilisation into the outlying parts of the earth.

The earliest ruling families claimed to possess the whole realm, and were enabled to divert much of the energies of their subjects to such purposes as the building of temples and palaces, and to the accumulation of the means of upkeep of such establishments. As a result of the combination of the domination of ruling families and their subsequent incessant struggles for power, there has ensued in all parts of the earth the decay and death of civilisations. The domination at home has apparently caused the arts and crafts to decay and become stereotyped, and the warfare engendered by these ruling classes has completed the work of destruction.

It remains to account for the fact that the daughter States were so much more warlike than those that gave rise to them. The explanation suggested by the facts is that the rulers of the original States were chiefly occupied with duties connected with the welfare of the communityfor this was the real source of their prestige-and were obliged incessantly to perform ceremonies for that end. They were hide-bound in etiquette, and apparently had but little personal initiative; but the young men who went out to found kingdoms threw over the restraints of their homes, and, with their followers, abandoned themselves to military pursuits, with results that are reflected in the social, economic, and religious life of the communities formed by them. One important consequence of this process was the formation in places of pastoral communities derived from those practising irrigation. These men, with checks and restraints removed, established the most warlike States that the world has known, and these States have ever been distinguished by cruelty beyond any that the world has known. It would seem 
that the psychological explanation of this phenomenon lies in the possession by these ruling classes of practically unrestrained power, which has caused them to adopt methods of cruelty.

This system of military domination, being inherently unstable, ultimately began to break down, and the peoples of Western Europe, released to some extent from the restraints imposed on mankind for so long by their ruling classes, were enabled to begin once more that progressive conquest of Nature which has so often and so rudely been interrupted in the past.

\section{Obituary.}

WE record with much regret the death of $D_{R}$. W. Ironside Bruce on March $2 I$ at the early age of forty-four. Dr. Bruce was educated at the University of Aberdeen, obtaining the degrees of M.B. and Ch.B. in I9oo, and then served as civil surgeon in the South African Field Force. Here he took much interest in the application of X-rays for the diagnosis of war injuries, and afterwards became assistant to the late Sir J. Mackenzie Davidson at Charing Cross Hospital, and on the death of the latter succeeded as medical officer in charge of the X-ray department. Dr. Bruce was intensely interested in the scientific developments of his subject, of which he acquired a very complete knowledge. He published "A System of Radiography with Atlas of the Normal," and in process of time became president of the section of radiology, Royal Society of Medicine, and took a considerable share in the establishment of the diploma in radiology, now given by the University of Cambridge. Some months ago the condition of his health gave rise to anxiety, and it was later found that he was suffering from a severe type of aplastic anæmia, from which he died. Evidence has accumulated that this condition may be caused by the more penetrating radiations both from $\mathrm{X}$-ray tubes and from radium, and there is little doubt that he succumbed as a result of his continuous work in radiology-another X-ray worker who may be described as a martyr to his science.

Lord Lonsdale has received the following letter from Buckingham Palace: "The King has learnt with much regret of the tragic death of Dr. Ironside Bruce, radiologist to the Charing Cross Hospital, and I am commanded to convey to you and the hospital staff his Majesty's sincere sympathy in the loss of so brilliant a physician, who sacrificed his life in the cause of science and humanity."

SCIENCE and industry alike have suffered a loss by the recent death, at Southall, of Mr. S. H. BLICHFEldT, a director of the Maypole Margarine Co. Mr. Blichfeldt was only forty-four years of age. He was of Danish birth, and took up a position as chemist at the Maypole works at Southall in 1906 after having worked for some years at Jörgensen's laboratory in Copenhagen. $\mathrm{He}$ was a strong advocate of the application of science to industry, and throughout his work demonstrated the importance of scientific methods in the factory, and the manufacture of margarine in the Maypole Co.'s works was gradually placed upon a really scientific basis as the result of his labours. Mr. Blichfeldt's abilities as a chemist and bacteriologist were widely known to the scientific world, and it is pleasing to note that the Maypole Co. recognised the value of research in industry, and appointed him a director of the company in I9I6.

Science for March II announces the death on February 2 of Prof. T. Mivake, of the Agricultural College of the Imperial University of Tokyo, who was the author of an important work on the entomology of Japan; and on February 24 of DR. F. J. V. SkIFF, director of the Field Museum, at the age of sixty-nine years.

THE death is announced, at eighty-three years of age, of Mr. JoHn Burroughs, the inspiring American writer on natural history subjects.

\section{Notes.}

Lecturing before the Royal Society of Medicine on March 22, Lt.-Col. Nathan Raw gave an account of his work and views on immunity in human tuberculosis. Col. Raw agrees with other investigators that man is attacked by two fundamentally different tuberculous viruses, the human and the bovine. The former is conveyed from person to person by direct infection and mainly attacks the lungs; the other is conveyed by milk from tuberculous cows and develops in the first few years of life. These two types of tubercle bacilli will not live in the body at the same time, and, further, an attack by one virus produces an immunity to the other. The bacilli may be attenuated by cultivating for years outside the body, so that they no longer convey the disease on inoculation into susceptible animals. Vaccines can be preNo. 2683 , vor. IO7] pared from these attenuated cultures, and may be em. ployed for the treatment of tuberculosis in man. Cases of infection with the human bacillus treated with the vaccine of the bovine virus have shown considerable improvement. Animals may be completely immunised against tuberculosis by the use of these attenuated cultures, and Col. Raw expressed the opinion that if all children with a tuberculous family history were vaccinated with the attenuated cultures, an entirely safe procedure, they would be in a much better position to resist infection in after years.

No section of scientific medicine has developed more rapidly in technique than those dealing with vaccines, sera, toxins, antitoxins, and related substances. The real science of these "biologic products" is scarcely a generation old. The use of 